KBC-29270-FP

Revision 0

\title{
Source Term Remediation and Demolition Strategy for the Hanford K-Area Spent Fuel Basins
}

Prepared for the U.S. Department of Energy

Assistant Secretary for Environmental Management

Project Hanford Management Contractor for the

U.S. Department of Energy under Contract DE-AC06-96RL13200

FLUOR.

P.O. Box 1000

Richland, Washington 
KBC-29270.FP

Revision 0

\title{
Source Term Remediation and Demolition Strategy for the Hanford K-Area Spent Fuel Basins
}

\author{
G. B. Chronister \\ Fluor Hanford \\ P. M. Knollmeyer \\ Fluor Hanford \\ March 2006 \\ To Be Presented at \\ 2006 Annual Conference \\ American Nuclear Society
}

*assote Published

Reno, Nevada

June 4-8, 2006

Prepared for the U.S. Department of Energy

Assistant Secretary for Environmental Management

Project Hanford Management Contractor for the

U.S. Department of Energy under Contract DE-AC06-96RL13200

\section{FLUOR。}

P.O. Box 1000

Richland, Washington

\section{Copyright License}

By acceptance of this article, the publisher and/or recipient acknowledges the U.S. Government's right to retain a nonexclusive, royalty-free license in and to any copyright covering this paper. 


\section{LEGAL DISCLAIMER}

This report was prepared as an account of work sponsored by an agency of the United States Government. Neither the United States Government nor any agency thereof, nor any of their employees, nor any of their contractors, subcontractors or their employees, makes any warranty, express or implied, or assumes any legal liability or responsibility for the accuracy, completeness, or any third party's use or the results of such use of any information, apparatus, product, or process disclosed, or represents that its use would not infringe privately owned rights. Reference herein to any specific commercial product, process, or service by trade name, trademark, manufacturer, or othenwise, does not necessarily constitute or imply its endorsement, recommendation, or favoring by the United States Government or any agency thereof or its contractors or subcontractors. The views and opinions of authors expressed herein do not necessarily state or reflect those of the United States Government or any agency thereof.

This document is available to the U.S. Department of Energy and its contractors, in paper from the Office of Scientific and Technical Information (OSTI). It is available for sale to the public from the National Technical Information Service (NTIS).

This report has been reproduced from the best available copy Available in paper copy. 


\title{
Source Term Remediation and Demolition Strategy for the Hanford K- Area Spent Fuel Basins
}

\author{
Glen B. Chronister \\ Peter M. Knollmeyer \\ Fluor Hanford \\ P.O. Box 1000; MSIN: X3-71 \\ Richland, WA 99352 \\ Glen_B_Chronister@rl.gov \\ Peter_Knollmeyer@r,r.gov
}

This paper discusses the technologies applied at Hanford's $\mathrm{K}$-Basins to mitigate risk and reduce the source term in preparing the basins for deactivation and demolition. These project technologies/strategies (in various stages of implementation) are sequential in nature and are the basis for preparing to dispose of the $\mathrm{K}$ Basins - two highly contaminated concrete basins at the Hanford Site in southeastern Washington State. A large collection of spent nuclear fuel stored for many years underwater at the $\mathrm{K}$ Basins has been removed to stable, dry, safe storage. Remediation activities are underway to prepare the basin structures for de-inventory, decontamination, and disposal.

The U. S. Department of Energy's (DOE) Hanford Site is considered the world's largest environmental cleanup project. The site covers $1,517 \mathrm{~km}^{2}$ (586 square miles) along the Columbia River in an arid region of the northwest United States (U.S.). Hanford is the largest of the U.S. former nuclear defense production sites. From the World War II era of the mid-1940s until the late- 1980s when production stopped Hanford produced 60 percent of the plutonium for nuclear defense, which resulted in a significant amount of environmental pollution that is now being addressed.

Spent nuclear fuel was among the major challenges for DOE's environmental cleanup mission at Hanford. The end of production left Hanford with about 105,000 irradiated, solid uranium metal fuel assemblies - representing approximately 2,100 metric tons. The fuel was ultimately stored in the K Basins' water-filled, concrete basins attached to Hanford's K East $(\mathrm{KE})$ and $\mathrm{K}$ West $(\mathrm{KW})$ reactors. $\mathrm{K}$ Basin's fuel accounted for 95 percent of the total radioactivity in Hanford's former reactor production areas.

Located about 457 meters $(500$ yards) from the Columbia River, the $\mathrm{K}$ Basins are two indoor, rectangular structures of reinforced concrete - each filled with more than 3.8 million liters (one million gallons) of water that has become highly contaminated with longlived radionuclides. At the $\mathrm{KW}$ Basin fuel was packaged and sealed in canisters. At the $\mathrm{KE}$ Basin fuel 
was stored in open canisters that were exposed to basin water. The irradiated spent nuclear fuel corroded during long-term, wet storage resulting in thousands of fuel assemblies becoming severely corroded and/or damaged.:Removal of the fuel inventory from the $\mathrm{KE}$ Basin was completed in 2005. It was transferred to the $\mathrm{KW}$ Basin where it was packaged and removed from that basin to dry storage on the Hanford site in calendar year 2005. The corrosion products from the fuel, especially in the $\mathrm{KE}$ Basin, contributed to the formation of a layer of radioactive sludge in the basins. Sludge removal is now progressing and will be followed by dewatering and dispositioning the concrete structures.

The DOE Richland Operations Office (RL) has given Fluor the task of preparing Hanford's $\mathrm{K}$ Basins for decontamination and disposal. Fluor is performing work in the $\mathrm{K}$ Basins to collect nominally 50 cubic meters of highly radioactive sludge. The sludge has been tentatively characaterized as remote handled transuranic (RHTRU) and awaiting approval of WIPP RH-TRU WAC. with the primary radiological constituents of concern being plutonium and cesium. There are no pyrophoricity concerns nor are there any criticality control issues needed for collection or treatment of the sludge. The sludge is collected through a pumping system and transferred to steel tanks set inside the basin. The pumping system includes a 6.35 -millimeter (1/4-inch) mesh screen to isolate larger particles of debris. The tanks or vessels provide interim storage until the sludge is transferred from the $\mathrm{KE}$ Basin to the $\mathrm{KW}$ Basin through a transfer line known as "hose in hose" or HIH. The HIH system utilizes four booster pump stations to ensure the sludge stays in suspension and transfers this slurry mixture to the $\mathrm{KW}$ Basin facility where it is collected in storage containers. These containers are also interim storage vessels. Finally, the sludge is transferred through a reconfigured $\mathrm{HIH}$ system to the 142-K Facility where it will undergo a high temperature water treatment designed to oxidize the remaining uranium metal "fines." This pretreatment to eliminate the potential for hydrogen generation must be done before this waste stream can be stabilized and dispositioned at an off-site repository.

After the sludge source term has been removed, the underwater surfaces of the basins will be decontaminated using a technology known as underwater hydrolasing. This process uses demineralized water at ultra-high pressures to scabble the highly radioactive concrete surfaces of the basins, while the basins are still filled with water. Once decontamination is complete, a specialized grout mixture will be applied underwater to encapsulate the remaining contaminated equipment. After the grout has been applied ( 6 feet $[2$ meters] of grout over the surface area of the basins), the water will be removed from the basins in preparation for demolishing the superstructure. Once the superstructure has been taken down, the below-ground installation - the pools - will be excavated to access the 38.7 meters 
